\title{
TACSTD2 upregulation is an early reaction to lung infection
}

Sára Lenárt ${ }^{1}$, Peter Lenárt ${ }^{1,2}$, Lucia Knopfová1,3, Hana Kotasová ${ }^{3,4}$, Vendula Pelková ${ }^{3,4}$, Veronika Sedláková ${ }^{4}$, Vladimír Čan ${ }^{5}$, Jan Šmarda ${ }^{1}$, Karel Souček ${ }^{1,3,6}$, Aleš Hampl ${ }^{3,4}$ and Petr Beneš $\breve{~}^{1,3 *}$

${ }^{1}$ Department of Experimental Biology, Faculty of Science, Masaryk University, Brno, Czech Republic

${ }^{2}$ Research Centre for Toxic Compounds in the Environment, Faculty of Science, Masaryk University, Brno, Czech Republic

${ }^{3}$ International Clinical Research Center, St. Anne's University Hospital, Brno, Czech Republic

${ }^{4}$ Department of Histology and Embryology, Faculty of Medicine, Masaryk University, Brno, Czech Republic

${ }^{5}$ Department of Surgery, University Hospital Brno, Brno, Czech Republic

${ }^{6}$ Department of Cytokinetics, Institute of Biophysics of the Czech Academy of Sciences, Brno, Czech Republic

*Author for correspondence: pbenes@sci.muni.cz

\begin{abstract}
TACSTD2 encodes a transmembrane glycoprotein Trop2 commonly overexpressed in carcinomas. While the Trop2 protein was discovered already in 1981 and first antibody-drug conjugate targeting Trop2 were recently approved cancer therapy, the physiological role of Trop2 is still not fully understood. In this article, we show that TACSTD2/Trop2 expression is evolutionarily conserved in lungs of various vertebrates. By analysis of publicly available transcriptomic data we demonstrate that TACSTD2 level consistently increases in lungs infected with miscellaneous pathogens. Single cell and subpopulation based transcriptomic data revealed that the major source of TACSTD2 transcript are lung epithelial cells and their progenitors and that TACSTD2 is induced directly in lung epithelial cells following infection. This increase may represent a mechanism to maintain/restore epithelial barrier function and contribute to regeneration process in infected/damaged lungs.
\end{abstract}


bioRxiv preprint doi: https:/doi.org/10.1101/2021.06 29.450320: this version posted June 30,2021 . The copyright holder for this preprint (which was not certified by peer review) is the author/funder, who has granted bioRxiv a license to display the preprint in perpetuity. It is made available under aCC-BY-NC-ND 4.0 International license.

\section{Introduction}

Trop2 is a transmembrane glycoprotein with yet unresolved physiological function, that is overexpressed in most carcinomas where it has been associated with cancer cell plasticity, tumor growth, metastasis and prognosis $(1,2)$. It is encoded by the intronless TACSTD2 (tumor-associated calcium signal transducer 2) gene belonging to TACSTD gene family (3). Genes of the TACSTD gene family are highly conserved across species; for instance, mouseTrop2 is $79.2 \%$ identical and $87.4 \%$ similar to human Trop2 $(4,5)$. Trop2 was originally found on the surface of trophoblast cells $(6)$ and has been subsequently identified on healthy epithelial cells of various other organs $(7,8)$. Trop2 is also expressed during normal embryonal and fetal development in lungs $(9,10)$, intestines (11), stomach (12), urinary bladder (13), kidneys (14), and cerebellum (15), however, its function in healthy adult tissues remains unknown.

In humans, congenital mutations of TACSTD2 cause a gelatinous drop-like corneal disease (GDLD), a rare autosomal recessive disease characterized by the development of bilateral corneal amyloidosis and eventually blindness (16). Loss of the Trop2 function leads to impaired subcellular localizations of tight junction-related proteins and loss of barrier function of corneal epithelial cells resulting in passage of Lactoferrin to subepithelial region where it forms amyloid deposits (17). Trop2 is also considered to be a stem/progenitor cell marker $(11,13,18-21)$ and several studies indicate that it might be associated with tissue remodeling and regeneration processes $(12,22,23)$. Surprisingly, the Tacstd2 null mice are fully viable, fertile, and without overt developmental abnormalities (24).

Lungs are vital organs inherently vulnerable to infection and injury due to constant exposure to pathogens, chemicals, and other air pollutants. The proper functions of epithelial barrier, immune system, and regenerative capacity of the lungs are thus crucial for restoring homeostasis following pathogen exposure or acute injury (25). The importance of lung homeostasis maintenance is further highlighted by the fact that even before the rise of SARS-CoV-2 pandemic, respiratory diseases belonged to leading causes of death worldwide (26). In this study, we use available expression datasets to test the hypothesis that the upregulation of TACSTD2 in the lungs is a physiological reaction to infection or injury, which both trigger an acute immune response (27-29).

\section{Methods}

\section{Lung expression data analysis}

In order to analyze TACSTD2/Trop2 expression in healthy lungs, several databases were searched. First, "TACSTD2" was searched in every species included in the Expression atlas database (30) (https://www.ebi.ac.uk/gxa/home, accessed on January 5, 2021). The results were filtered for baseline lung expression in each organism. From each study, information about expression level and the number of biological replicates was retrieved. The expression value was set to 0.5. 
bioRxiv preprint doi: https:/doi.org/10.1101/2021.06 29.450320; this version posted June 30 2021. The copyright holder for this preprint (which was not certified by peer review) is the author/funder, who has granted bioRxiv a license to display the preprint in perpetuity. It is made available under aCC-BY-NC-ND 4.0 International license.

"TACSTD2" was also searched in The Human Protein Atlas (31) (https://www.proteinatlas.org/, accessed on January 5, 2021) where the Tissue atlas was selected, and Lung was chosen to obtain RNA and protein expression data.

"TACSTD2" was also searched in GTEx Portal (32) (https://www.gtexportal.org/home/, accessed on January 5, 2021, dbGaP accession number: phs000424.v8.p2). Even though, data we used from GTEx are also available in Expression Atlas and The Human Protein Atlas, the GTEx is the primary source and data in other databases are not always up to date. Therefore, when data were available from multiple sources, we used data from GTEx for analyses.

Furthermore, "TACSTD2" was searched in Bgee database (33) (https://bgee.org/, accessed on January 5, 2021). Because Bgee database uses ArrayExpress, GEO, and GTEx - dbGAP as sources of raw data, and the same sources are also used by the Expression Atlas, TACSTD2 expression data from Bgee were used only for animals which TACSTD2 expression profile was not listed in Expression Atlas database, i.e., pig, chimpanzee, macaque, rabbit, and opossum (see Suplementary Data S1).

\section{Differential expression data analysis}

To test the hypothesis that the overexpression of TACSTD2 in the lungs is a physiological reaction to infection or injury, we first analyzed differential TACSTD2 expression data for every species included in the Expression atlas database (30) (https://www.ebi.ac.uk/gxa/home, accessed on January 5, 2021). Results were filtered by choosing Infect or Injury in Experimental variables. Subsequently, only studies that met the following criteria were included:

1. The dataset must contain data from experiments with whole organisms, not cell lines.

2. The dataset provides information about lung transcriptome.

3. The dataset allows identification of differentially expressed genes following infection or injury.

Additionally, the E-GEOD-33266 dataset, which was not found by the above-described approach as it did not contain the keyword "Infect" in its annotation, was identified by searching Expression Atlas COVID-19 Data Portal.

In each particular study, $\log _{2}$-fold change value was set to 0.0 so we could see even the small change of TACSTD2 expression. The adjusted p-value was set to 1 , so we could see non-significant results as well. P-values were adjusted for multiple testing using the Benjamini and Hochberg false discovery rate (FDR) correction (34).

In order to pinpoint cell population(s) responsible for the increase of TACSTD2/Trop2 after infection in the lungs, we searched for datasets in Gene Expression Omnibus (GEO) (35) containing sorted cell populations from infected lungs or infected cell cultures in vitro. Expression values for 
bioRxiv preprint doi: https://doi.org/10.1101/2021.06 29.450320; this version posted June 30,2021 . The copyright holder for this preprint (which was not certified by peer review) is the author/funder, who has granted bioRxiv a license to display the preprint in perpetuity. It is made available under aCC-BY-NC-ND 4.0 International license.

TACSTD2/Tacstd2 from indicated datasets were retrieved, plotted and analyzed using GraphPad Prism v6.07 and shown in heat map using FGCZ Heatmap tool (http://fgcz-shiny.uzh.ch).

\section{Immunohistochemistry}

The sample of human lungs was obtained from therapeutical surgery based on the written informed consent by the patient and approval of Ethics Committee of the University Hospital Brno (28170621/EK). The specimens of pig, rat, mouse and human lungs were fixed with formalin, washed with PBS, dehydrated through series of alcohols (70\%, 80\%, and 96\%) and embedded in paraffin blocks. Sections ( $4 \mu \mathrm{m}$ thick) were dewaxed in xylene, hydrated through a graded series of alcohols $(96 \%, 80 \%$, and 70\%), and rinsed in deionized water. After antigen retrieval in citrate buffer (pH 9.0, $12 \mathrm{~min}$ ) at 98 ${ }^{\circ} \mathrm{C}$ for 30 min., the slides were rinsed in tap and deionized water and washed with $3 \% \mathrm{H}_{2} \mathrm{O}_{2}$ in PBS at room temperature (RT) for 10 min. To block endogenous peroxidase activity, the sections were treated with $10 \%$ fetal bovine serum for $30 \mathrm{~min}$. The sections were incubated with the primary antibody against TROP2 (Abcam, ab227689, 1:100) for $1 \mathrm{~h}$ at RT. The slides were then washed three times in PBS and subsequently incubated with the secondary antibody (En Vision FLEX/HRP) for 20 min. After the last washing step, the slides were incubated in substrate solution (DAB), counterstained in hematoxylin, dehydrated with alcohols and xylene, and mounted. 


\section{Results}

\section{TACSTD2/Trop2 expression in lungs}

To test the hypothesis that upregulation of TACSTD2/Trop2 is a physiological reaction to lung tissue damage by infection or injury, we first verified that TACSTD2 is indeed expressed in healthy lungs. Analysis of available datasets shows overwhelming evidence that the TACTSD2 gene is expressed in lungs of all studied species (Table 1). This suggests that TACSTD2 has an evolutionarily conserved role in the function of lungs. A more detailed table is available in Supplementary data S1.

\begin{tabular}{|l|c|}
\hline \multicolumn{1}{|c|}{ Organism } & Number of subjects \\
\hline Human (Homo sapiens) & $601 / 601^{*}$ \\
\hline Mouse (Mus musculus) & $27 / 27^{*}$ \\
\hline Cattle (Bos taurus) & $4 / 4$ \\
\hline Chicken (Gallus gallus) & $3 / 3$ \\
\hline Sheep (Ovis aries) & $4 / 4$ \\
\hline Olive baboon (Papio anubis) & $1 / 1$ \\
\hline Rat (Rattus norvegicus) & $35 / 35$ \\
\hline Pig (Sus scrofa) & $2 / 4$ \\
\hline Chimpanzee (Pan troglodytes) & $1 / 1$ \\
\hline Macaque (Macaca mulata) & $1 / 1$ \\
\hline Rabbit (Oryctolagus cuniculus) & $1 / 1$ \\
\hline Opossum (Monodelphis domestica) & $1 / 1$ \\
\hline
\end{tabular}

Table 1. List of studied organisms with TACSTD2 expression in lungs. The number of subjects reflect the sum of biological replicates from transcriptomic datasets. * Trop2 expression was also found in human lungs in two of three proteomics datasets. The level of mouse Trop2 was below the cutoff in the one available proteomic dataset (see Supplementary data S1).

To find which cell types produce TACSTD2 in the lungs, we searched the Human Protein Atlas. The highest expression has been detected in alveolar cells type I and II, club cells and ciliated cells but smaller amounts of TACSTD2 were also expressed in lung's immune cells such as macrophages, T-cells, and granulocytes (Figure 1A). Recently, single cell transcriptomic analysis revealed that out of 58 molecular cell types identified in human lungs, TACSTD2 is enriched in basal, differentiating basal, proliferating basal, proximal basal, goblet, alveolar epithelial type 1, platelets, and myeloid dendritic cells (Figure 1B) (36). 


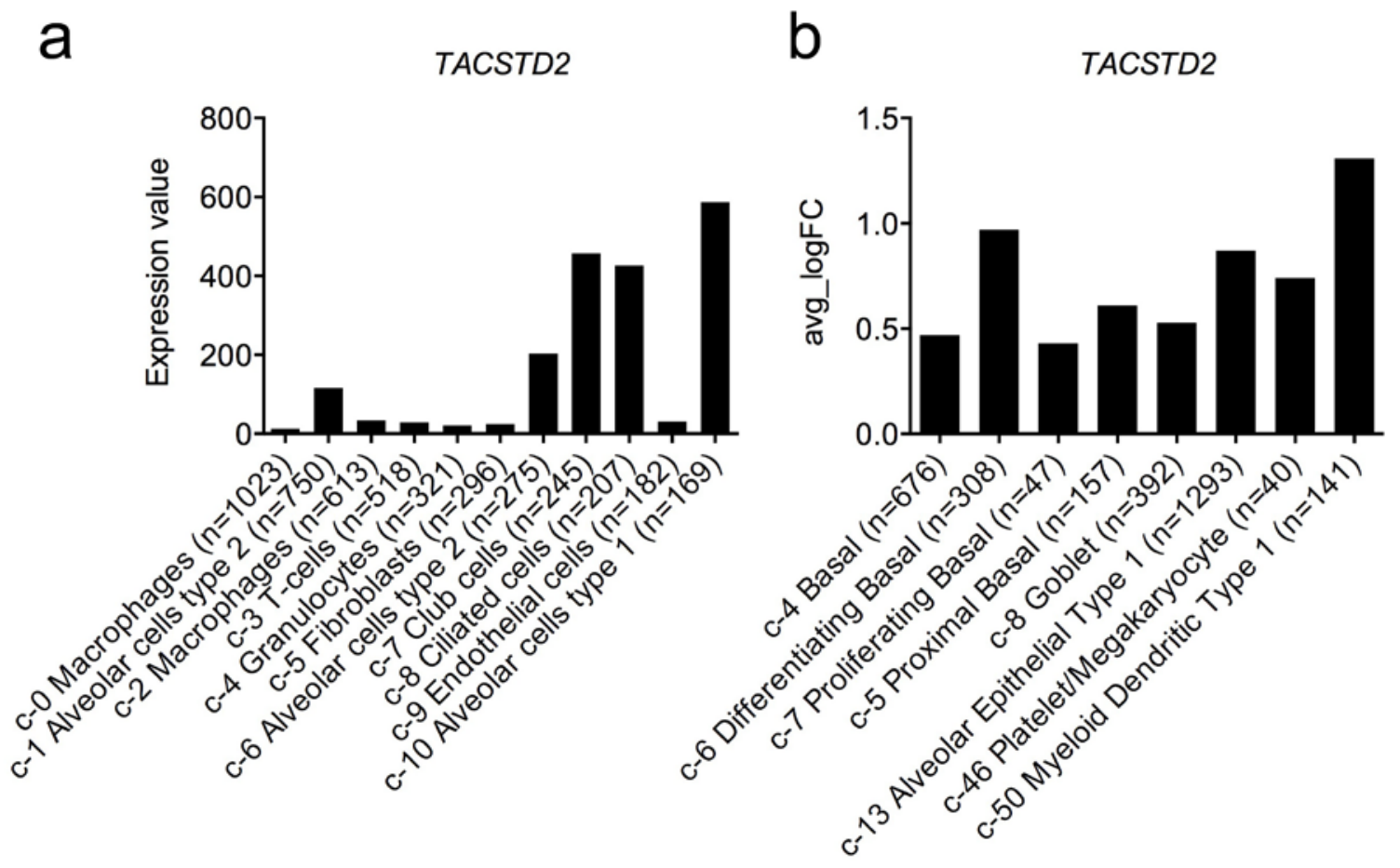

Figure 1. TACSTD2 expression in cell clusters of human lungs identified by single cell RNAsequencing. A) RNA expression (PTPM) in the cell type clusters identified in lung visualized by a bar chart, retrieved from Human Protein Atlas. Single cell transcriptomic dataset of Vieira Braga FA et al. (2019) (GSE130148) (37) was used. B) Cell clusters with significantly $(p<0.05)$ enriched TACSTD2 expression as identified in human lungs by Travaglini et al. 2020 (36). Chart shows the natural log of the average fold change between the indicated cell type and other cell types in lungs. $c=$ cluster number, with main cell type annotated, $n=$ number of included cells.

Interestingly, one mouse (E-MTAB-3579) and one rat (E-GEOD-53960) (38) dataset evaluated transcripts at different stages of embryonal development and at different stages of postnatal life. In these datasets, Tacstd2 expression increased with age (Figure 2A and 2C). This has been recently confirmed by Angelidis et al., who detected significantly higher Tacstd2 mRNA in the bulk lung RNA of 24months-old mice than in the lungs of 3-months-old mice (Figure 2B). Single cell transcriptomic approach, however, did not reveal the source of this increase (39). 


\section{a}

Tacstd2 expression in mouse lungs



b

Tacstd2 expression in mouse lungs
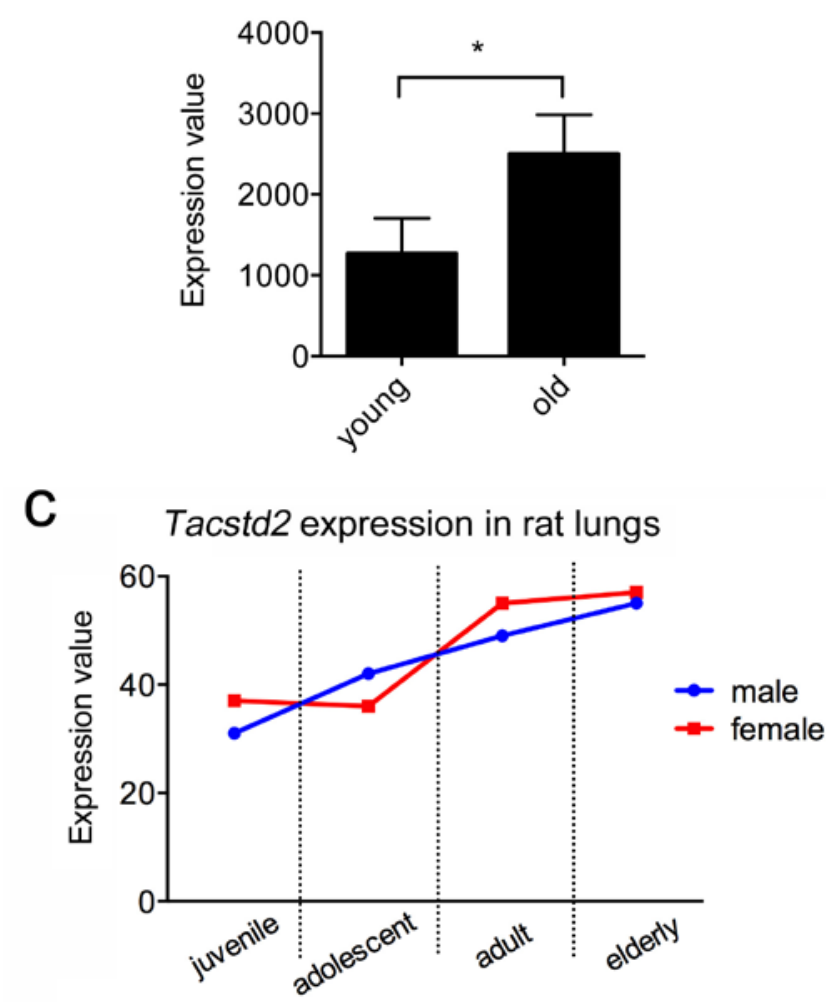

Figure 2. Tacstd2 gene expression in lungs (bulk data) of A) six mice during embryonal development, five neonate, two juvenile mice and one adult mouse (E-MTAB-3579). B) three replicates of young (3 months) and old mice (24 months) (39). C) juvenile (2 weeks), adolescent (6 weeks), adult (21 weeks) and elderly (104 weeks) female and male rats (E-GEOD-53960) (38). Four biological replicates were used for each sex and developmental stage.

To confirm that Trop2 protein is expressed in lungs of various organisms we performed IHC analysis in paraffin sections of human, mouse and pig lung tissues. In human lungs, Trop2 staining was observed in membranes of airway and alveolar epithelial cells while only basolateral parts of airway epithelium was Trop2 positive in mouse and pig lungs (Figure 3, Supplementary Figure S1). These data 
bioRxiv preprint doi: https://doi.org/10.1101/2021.06 29.450320; this version posted June 30, 2021. The copyright holder for this preprint (which was not certified by peer review) is the author/funder, who has granted bioRxiv a license to display the preprint in perpetuity. It is made available under aCC-BY-NC-ND 4.0 International license.

confirms that Trop2 is produced by lung epithelial cells but also point to differences in its expression pattern in lungs of selected vertebrates.

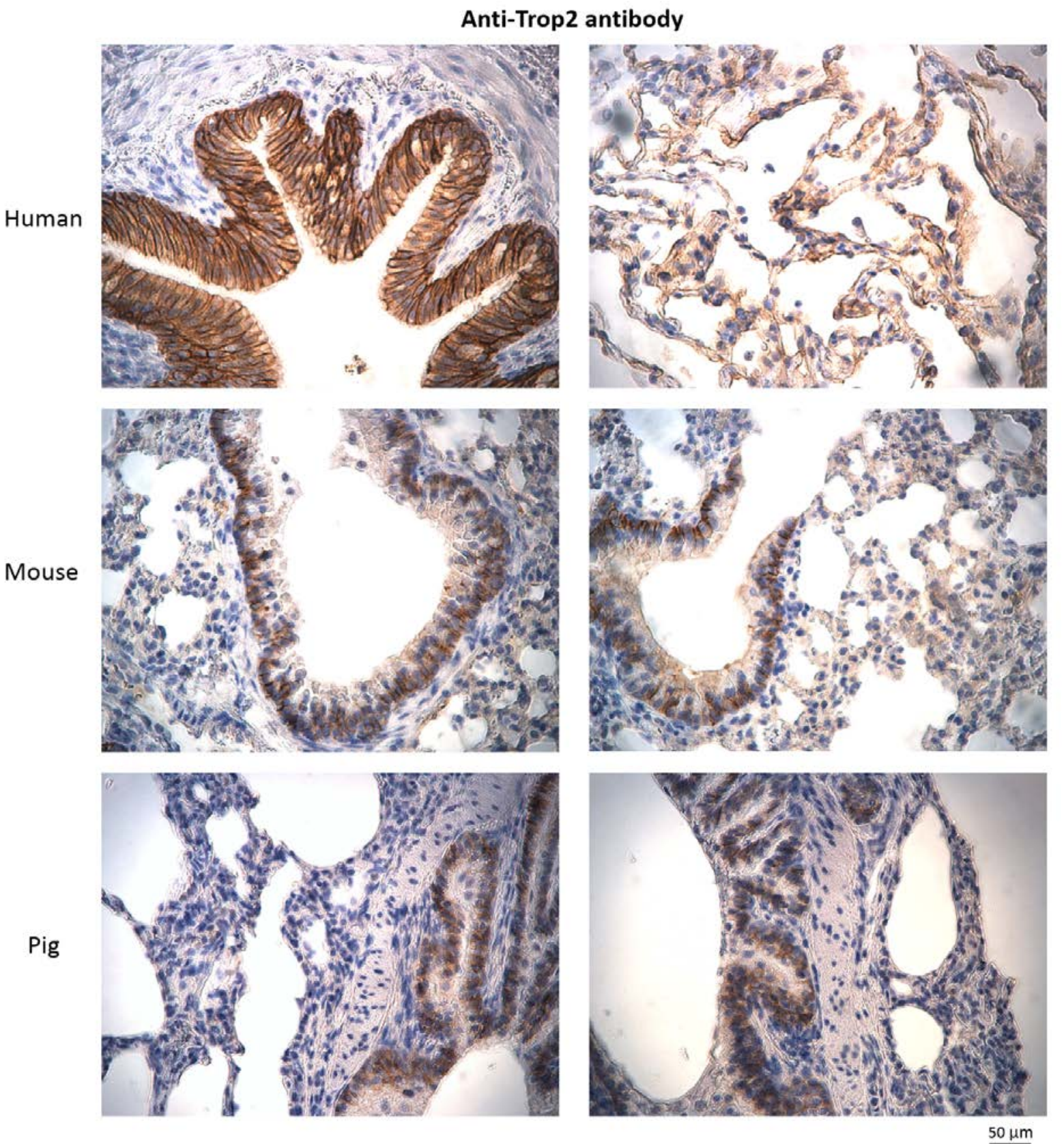

Figure 3. Immunohistochemical detection of Trop2 in paraffin sections of human, mouse and pig

lung tissue. Human lungs - positive staining in epithelium of airway and alveoli. Mouse/Pig lungs positive staining only in basolateral parts of airway epithelium. 
bioRxiv preprint doi: https:/doi.org/10.1101/2021.06 29.450320: this version posted June 30,2021 . The copyright holder for this preprint (which was not certified by peer review) is the author/funder, who has granted bioRxiv a license to display the preprint in perpetuity. It is made available under aCC-BY-NC-ND 4.0 International license.

\section{Upregulation of TACSTD2 in infected lungs}

Next, to analyze TACSTD2 expression in response to lung damage, we searched the Expression Atlas database for differential expression in lungs after infection or injury. Eleven differential expression datasets analyzed the levels of Tacstd2 early after infection (1-7 days), and all of them showed a significant upregulation of Tacstd2 in infected mouse lungs (Table 2). This increase was observed in both males and females, 9 different mouse strains, at various ages (8-20 weeks), and with various infectious agents. Datasets containing information about the dynamics of this process showed that in the case of SARS coronavirus MA15, the levels of Tacstd2 peaked two days post-infection and then started to decrease, indicating that the upregulation of Tacstd2 is an early reaction to infection (Table 2, Figure 4). After infection with the influenza A virus, Tacstd2 levels peaked on the fourth day, but the increase rate was reduced after the second day confirming that Tacstd2 elevation is an early response (Table 2). Particularly intriguing is the E-GEOD-33266 dataset, where various doses of SARS coronavirus were used for infecting mice. Analysis of this dataset not only confirmed that Tacstd2 levels were highest two days after SARS coronavirus infection regardless of the infection dose but also showed that a higher dose of the virus induced higher upregulation of TACSTD2 (Table 2).

Interestingly, two datasets that tested Tacstd2 expression after a longer time (Table 2). Lungs of mice infected with Mycobacterium tuberculosis H37Rv were analyzed after 28 days. In wild type C57BL/6 mice, there was no difference in Tacstd2 expression levels in comparison to their level prior to infection, which is in agreement with other studies showing that Tacstd2 is upregulated early after infection. However, when TNF- $\alpha$ knockout mice were infected, an enhanced bacterial burden, high inflammation, oedema, necrosis and increased Tacstd2 level were detected in the lungs after 28 days. The second dataset evaluated transcriptome in mice infected with the Sendai virus. Interestingly, in this case Tacstd 2 was also upregulated late post-infection (21 and 49 days). Although, at the first sight, it might seem inconsistent with other studies, mice from this dataset developed chronic airway disease similar to human chronic airway diseases, such as asthma and COPD (40). Thus, the long upregulation of Tacstd2 reflects the known upregulation of TACSTD2 in human COPD (41), possibly triggered by chronic lung damage. 


\begin{tabular}{|c|c|c|c|c|c|c|c|c|}
\hline $\begin{array}{c}\text { ArrayExpress } \\
\text { accession number }\end{array}$ & Infect & $\begin{array}{c}\text { Time } \\
\text { (days) }\end{array}$ & $\begin{array}{l}\log _{2} \text {-fold } \\
\text { change }\end{array}$ & $\begin{array}{l}\text { Adjusted } \\
\text { p-value }\end{array}$ & $\begin{array}{c}\text { Number of } \\
\text { subjects }\end{array}$ & Strain & Age & Sex \\
\hline \multirow[t]{8}{*}{ E-GEOD-49262 } & \multirow{4}{*}{$\begin{array}{l}\text { SARS coronavirus MA15 dORF6 } \\
\text { vs none }\end{array}$} & 1 & 0.1 & 0.423 & 3 vs 3 & \multirow[t]{4}{*}{$\mathrm{C} 57 \mathrm{BL} / 6 \mathrm{~J}$} & \multirow[t]{4}{*}{20 week } & \multirow[t]{4}{*}{ mixed } \\
\hline & & 2 & 2.4 & $<0.001$ & 3 vs 3 & & & \\
\hline & & 4 & 1.2 & 0.001 & 3 vs 3 & & & \\
\hline & & $7 *$ & 1.2 & $\mathrm{~N} / \mathrm{A}$ & 3 vs 2 & & & \\
\hline & \multirow{4}{*}{$\begin{array}{l}\text { SARS coronavirus MA15 vs } \\
\text { none }\end{array}$} & 1 & 1.3 & 0.001 & 3 vs 3 & \multirow[t]{4}{*}{ C57BL/6J } & \multirow[t]{4}{*}{20 week } & \multirow[t]{4}{*}{ mixed } \\
\hline & & 2 & 2.3 & $<0.001$ & 3 vs 3 & & & \\
\hline & & 4 & 1 & 0.002 & 3 vs 3 & & & \\
\hline & & $7^{*}$ & 1.4 & $\mathrm{~N} / \mathrm{A}$ & 3 vs 2 & & & \\
\hline \multirow[t]{8}{*}{ E-GEOD-49263 } & \multirow{4}{*}{$\begin{array}{l}\text { SARS coronavirus MA15 } \\
\text { nsp16-/- vs none }\end{array}$} & $1^{*}$ & 1.3 & $\mathrm{~N} / \mathrm{A}$ & 3 vs 2 & \multirow[t]{4}{*}{ C57BL/6J } & \multirow[t]{4}{*}{10 week } & \multirow[t]{4}{*}{ mixed } \\
\hline & & 2 & 2.3 & $<0.001$ & 4 vs 3 & & & \\
\hline & & 4 & 0.9 & 0.006 & 3 vs 3 & & & \\
\hline & & 7 & 0.1 & 0.747 & 4 vs 3 & & & \\
\hline & \multirow{4}{*}{$\begin{array}{l}\text { SARS coronavirus MA15 vs } \\
\text { none }\end{array}$} & $1 *$ & 1.4 & $\mathrm{~N} / \mathrm{A}$ & 4 vs 2 & \multirow[t]{4}{*}{ C57BL/6J } & \multirow[t]{4}{*}{10 week } & \multirow[t]{4}{*}{ mixed } \\
\hline & & 2 & 2.4 & $<0.001$ & 4 vs 3 & & & \\
\hline & & 4 & 1.2 & $<0.001$ & 4 vs 3 & & & \\
\hline & & 7 & 0.5 & 0.055 & 3 vs 3 & & & \\
\hline \multirow[t]{6}{*}{ E-GEOD-50878 } & \multirow{3}{*}{$\begin{array}{l}\text { SARS coronavirus MA15 vs } \\
\text { none }\end{array}$} & 2 & 2 & $<0.001$ & 3 vs 9 & \multirow[t]{3}{*}{ C57BL/6J } & \multirow[t]{3}{*}{10 week } & \multirow[t]{3}{*}{ not available } \\
\hline & & $4^{*}$ & 1.1 & $\mathrm{~N} / \mathrm{A}$ & 2 vs 9 & & & \\
\hline & & 7 & 0.3 & 0.040 & 3 vs 9 & & & \\
\hline & \multirow{3}{*}{$\begin{array}{l}\text { SARS coronavirus MA15 vs } \\
\text { none }\end{array}$} & 2 & 2.2 & $<0.001$ & 3 vs 7 & \multirow{3}{*}{$\begin{array}{l}\text { C57BL/6J } \\
\text { CXCR3 knockout }\end{array}$} & \multirow[t]{3}{*}{10 week } & \multirow[t]{3}{*}{ not available } \\
\hline & & $4 *$ & 1.2 & $\mathrm{~N} / \mathrm{A}$ & 2 vs 7 & & & \\
\hline & & 7 & 0.4 & 0.146 & 4 vs 7 & & & \\
\hline \multirow[t]{8}{*}{ E-GEOD-52405 } & \multirow{8}{*}{$\begin{array}{l}\text { SARS coronavirus MA15 vs } \\
\text { mock }\end{array}$} & 2 & 1.5 & $<0.001$ & 3 vs 4 & 129S1/SvImJ & 8 to 16 week & female \\
\hline & & 4 & 0.7 & $<0.001$ & 3 vs 4 & & & \\
\hline & & 2 & 2 & $<0.001$ & 3 vs 4 & C57BL/6J & 8 to 16 week & female \\
\hline & & 4 & 1 & $<0.001$ & 3 vs 4 & & & \\
\hline & & 2 & 0.9 & $<0.001$ & 3 vs 4 & CAST/EiJ & 8 to 16 week & female \\
\hline & & 4 & 0.6 & 0.134 & 3 vs 4 & & & \\
\hline & & 2 & 1.4 & $<0.001$ & 3 vs 4 & NOD/ShiLtJ & 8 to 16 week & female \\
\hline & & 4 & 0.8 & $<0.001$ & 3 vs 4 & & & \\
\hline
\end{tabular}




\begin{tabular}{|c|c|c|c|c|c|c|c|c|}
\hline & 2 & 1.5 & $<0.001$ & 3 vs 4 & \multirow[t]{2}{*}{$\mathrm{PWK} / \mathrm{PhJ}$} & \multirow[t]{2}{*}{8 to 16 week } & \multirow[t]{2}{*}{ female } \\
\hline & & 4 & 1.8 & $<0.001$ & 3 vs 4 & & & \\
\hline & & 2 & 1.6 & $<0.001$ & 3 vs 4 & \multirow[t]{2}{*}{ WSB/EiJ } & \multirow[t]{2}{*}{8 to 16 week } & \multirow[t]{2}{*}{ female } \\
\hline & & 4 & 1 & $<0.001$ & 3 vs 4 & & & \\
\hline & & 4 & 1.7 & $<0.001$ & 3 vs 4 & $\mathrm{~A} / \mathrm{J}$ & 8 to 16 week & female \\
\hline & \multirow{14}{*}{$\begin{array}{l}\text { Influenza A virus (A/Puerto } \\
\text { Rico/8/1934(H1N1)) (10² PFU) } \\
\text { vs mock }\end{array}$} & 2 & 1.2 & $<0.001$ & 3 vs 4 & \multirow[t]{2}{*}{ 129S1/SvImJ } & \multirow[t]{2}{*}{8 to 16 week } & \multirow[t]{2}{*}{ female } \\
\hline & & 4 & 0.9 & $<0.001$ & 3 vs 4 & & & \\
\hline & & 2 & 1.4 & $<0.001$ & 3 vs 4 & \multirow[t]{2}{*}{$A / J$} & \multirow[t]{2}{*}{8 to 16 week } & \multirow[t]{2}{*}{ female } \\
\hline & & 4 & 0.9 & 0.002 & 3 vs 4 & & & \\
\hline & & 2 & 1.8 & $<0.001$ & 3 vs 4 & \multirow[t]{2}{*}{ NOD/ShiLtJ } & \multirow[t]{2}{*}{8 to 16 week } & \multirow[t]{2}{*}{ female } \\
\hline & & 4 & 1.5 & $<0.001$ & 3 vs 4 & & & \\
\hline & & 2 & 0.7 & 0.172 & 3 vs 4 & \multirow[t]{2}{*}{$\mathrm{C} 57 \mathrm{BL} / 6 \mathrm{~J}$} & \multirow[t]{2}{*}{8 to 16 week } & \multirow[t]{2}{*}{ female } \\
\hline & & 4 & 1.1 & $<0.001$ & 3 vs 4 & & & \\
\hline & & 2 & 0.6 & 0.141 & 3 vs 4 & \multirow[t]{2}{*}{ NZO/HILtJ } & \multirow[t]{2}{*}{8 to 16 week } & \multirow[t]{2}{*}{ female } \\
\hline & & 4 & 1.3 & 0.008 & 3 vs 4 & & & \\
\hline & & 4 & 1.1 & $<0.001$ & 3 vs 4 & PWK/PhJ & 8 to 16 week & female \\
\hline & & 2 & 0.8 & $<0.001$ & 3 vs 4 & CAST/EiJ & 8 to 16 week & female \\
\hline & & 2 & 0.4 & 0.406 & 3 vs 4 & \multirow[t]{2}{*}{ WSB/EiJ } & \multirow[t]{2}{*}{8 to 16 week } & \multirow[t]{2}{*}{ female } \\
\hline & & 4 & 1.3 & $<0.001$ & 3 vs 4 & & & \\
\hline \multirow[t]{6}{*}{ E-GEOD-68820 } & \multirow{6}{*}{$\begin{array}{l}\text { SARS coronavirus MA15 vs } \\
\text { mock }\end{array}$} & 2 & 2 & $<0.001$ & 5 vs 4 & \multirow{3}{*}{$\begin{array}{l}\text { C57BL/6NJ } \\
\text { TLR3 knockout }\end{array}$} & \multirow[t]{3}{*}{10 week } & \multirow[t]{3}{*}{ female } \\
\hline & & 4 & 1.2 & $<0.001$ & 5 vs 4 & & & \\
\hline & & 7* & -0.02 & N/A & 5 vs 2 & & & \\
\hline & & 2 & 2 & $<0.001$ & 5 vs 5 & C57BL/6NJ & 10 week & female \\
\hline & & 4 & 0.6 & $<0.001$ & 4 vs 5 & & & \\
\hline & & 7 & -0.2 & 0.230 & 4 vs 4 & & & \\
\hline E-GEOD-59185 & $\begin{array}{l}\text { SARS coronavirus MA15 vs } \\
\text { mock }\end{array}$ & 2 & 1.9 & $<0.001$ & 3 vs 3 & $\mathrm{BALB} / \mathrm{c}$ & 16 week & female \\
\hline & $\begin{array}{l}\text { SARS coronavirus MA15 E } \\
\text { protein mutant } \Delta 3 \text { vs mock }\end{array}$ & 2 & 1.5 & 0.002 & 3 vs 3 & $\mathrm{BALB} / \mathrm{c}$ & 16 week & female \\
\hline & $\begin{array}{l}\text { SARS coronavirus MA15 } \mathrm{E} \\
\text { protein mutant } \Delta 5 \text { vs mock }\end{array}$ & 2 & - & - & 3 vs 3 & $\mathrm{BALB} / \mathrm{c}$ & 16 week & female \\
\hline
\end{tabular}




\begin{tabular}{|c|c|c|c|c|c|c|c|c|}
\hline & $\begin{array}{l}\text { SARS coronavirus MA15 lacking } \\
\text { full-length E protein vs mock }\end{array}$ & 2 & 0.5 & 0.179 & 3 vs 3 & $\mathrm{BALB} / \mathrm{c}$ & 16 week & female \\
\hline \multirow[t]{2}{*}{ E-MTAB-5218 } & \multirow{2}{*}{$\begin{array}{l}\text { Mycobacterium tuberculosis } \\
\text { H37Rv (1000 } \pm 300 \mathrm{CFU}) \text { vs } \\
\text { none }\end{array}$} & 28 & 1.6 & $<0.001$ & 4 vs 3 & $\begin{array}{l}\text { C57BL/6 } \\
\text { TNF- } \alpha \text { knock-out }\end{array}$ & 8 to 12 week & female \\
\hline & & 28 & - & - & 10 vs 9 & $\mathrm{C} 57 \mathrm{BL} / 6$ & 8 to 12 week & female \\
\hline \multirow[t]{6}{*}{ E-GEOD-51386 } & \multirow{6}{*}{$\begin{array}{l}\text { SARS coronavirus MA15 }\left(10^{4}\right. \\
\text { PFU) vs mock }\end{array}$} & 4 & 1.4 & $<0.001$ & 4 vs 4 & \multirow[t]{2}{*}{$\mathrm{C} 57 \mathrm{BL} / 6$} & \multirow[t]{2}{*}{20 week } & \multirow[t]{2}{*}{ not available } \\
\hline & & 7 & 0.9 & $<0.001$ & 3 vs 4 & & & \\
\hline & & 4 & 1.1 & $<0.001$ & 4 vs 4 & \multirow{2}{*}{$\begin{array}{l}\text { C57BL/6 } \\
\text { PAI1 knockout }\end{array}$} & \multirow[t]{2}{*}{20 week } & \multirow[t]{2}{*}{ not available } \\
\hline & & 7 & 0.8 & 0.001 & 3 vs 4 & & & \\
\hline & & 4 & 1.1 & $<0.001$ & 4 vs 4 & \multirow{2}{*}{$\begin{array}{l}\text { C57BL/6 } \\
\text { TIMP1 knockout }\end{array}$} & \multirow[t]{2}{*}{20 week } & \multirow[t]{2}{*}{ not available } \\
\hline & & 7 & 0.6 & 0.020 & 4 vs 4 & & & \\
\hline \multirow[t]{2}{*}{ E-MTAB-6044 } & $\begin{array}{l}\text { Influenza A virus (500 PFU) vs } \\
\text { mock (IgG1 isotype control) }\end{array}$ & 7 & 1.1 & $<0.001$ & 4 vs 3 & $\mathrm{C} 57 \mathrm{BL} / 6$ & 8 to 10 week & male \\
\hline & $\begin{array}{l}\text { Influenza A virus (500 PFU) vs } \\
\text { mock } \\
\text { (treatment with interleukin-22) }\end{array}$ & 7 & 1.3 & $<0.001$ & 4 vs 4 & $\mathrm{C} 57 \mathrm{BL} / 6$ & 8 to 10 week & male \\
\hline \multirow[t]{4}{*}{ E-GEOD-51387 } & \multirow{4}{*}{$\begin{array}{l}\text { SARS coronavirus MA15 vs } \\
\text { mock }\end{array}$} & 4 & 1.2 & $<0.001$ & 3 vs 4 & \multirow[t]{2}{*}{$\mathrm{C57BL} / 6$} & \multirow[t]{2}{*}{20 week } & \multirow[t]{2}{*}{ not available } \\
\hline & & 7* & 1 & N/A & 2 vs 4 & & & \\
\hline & & $4 *$ & 1.5 & $\mathrm{~N} / \mathrm{A}$ & 2 vs 4 & \multirow{2}{*}{$\begin{array}{l}\text { C57BL/6 } \\
\text { PLAT knockout }\end{array}$} & \multirow[t]{2}{*}{20 week } & \multirow[t]{2}{*}{ not available } \\
\hline & & 7 & 0.5 & $<0.001$ & 3 vs 4 & & & \\
\hline \multirow[t]{2}{*}{ E-GEOD-10964 } & $\begin{array}{l}\text { active Sendai virus vs UV- } \\
\text { inactivated Sendai virus } \\
\text { (Affymetrix MOE430A Array) }\end{array}$ & 21 & 1.2 & 0.013 & 3 vs 3 & $\mathrm{C} 57 \mathrm{BL} / 6 \mathrm{~J}$ & 3 to 5 week & male \\
\hline & $\begin{array}{l}\text { active Sendai virus vs UV- } \\
\text { inactivated Sendai virus } \\
\text { (Affymetrix Mouse430_2 Array) }\end{array}$ & 49 & 1 & 0.002 & 3 vs 3 & C57BL/6J & 3 to 5 week & male \\
\hline \multirow[t]{4}{*}{ E-GEOD-40824 } & \multirow{4}{*}{$\begin{array}{l}\text { SARS coronavirus MA15 vs } \\
\text { none }\end{array}$} & 4 & 1.1 & $<0.001$ & 3 vs 3 & \multirow[t]{2}{*}{ C57BL/6J } & \multirow[t]{2}{*}{10 week } & \multirow[t]{2}{*}{ female } \\
\hline & & 7 & 0.2 & 0.247 & 3 vs 3 & & & \\
\hline & & 4 & 1 & $<0.001$ & 3 vs 3 & \multirow{2}{*}{$\begin{array}{l}\text { C57BL/6J } \\
\text { Tnfrsf1a/1b } \\
\text { knockout }\end{array}$} & \multirow[t]{2}{*}{10 week } & \multirow[t]{2}{*}{ female } \\
\hline & & 7* & -0.02 & N/A & 2 vs 2 & & & \\
\hline
\end{tabular}




\begin{tabular}{|c|c|c|c|c|c|c|c|c|}
\hline \multirow[t]{16}{*}{ E-GEOD-33266 } & \multirow{4}{*}{$\begin{array}{l}\text { SARS coronavirus MA15 }\left(10^{2}\right. \\
\text { PFU) vs none }\end{array}$} & 1 & 0.3 & 0.066 & 5 vs 3 & \multirow[t]{4}{*}{ C57BL/6 } & \multirow[t]{4}{*}{20 week } & \multirow[t]{4}{*}{ female } \\
\hline & & 2 & 0.2 & 0.639 & 5 vs 3 & & & \\
\hline & & 4 & 0.2 & 0.345 & 5 vs 3 & & & \\
\hline & & 7 & -0.1 & 0.687 & 5 vs 3 & & & \\
\hline & \multirow{4}{*}{$\begin{array}{l}\text { SARS coronavirus MA15 }\left(10^{3}\right. \\
\text { PFU) vs none }\end{array}$} & 1 & 0.2 & 0.208 & 5 vs 3 & \multirow[t]{4}{*}{ C57BL/6 } & \multirow[t]{4}{*}{20 week } & \multirow[t]{4}{*}{ female } \\
\hline & & 2 & 1.1 & 0.018 & 5 vs 3 & & & \\
\hline & & 4 & 0.8 & $<0.001$ & 5 vs 3 & & & \\
\hline & & 7 & -0.1 & 0.667 & 5 vs 3 & & & \\
\hline & \multirow{4}{*}{$\begin{array}{l}\text { SARS coronavirus MA15, }\left(10^{4}\right. \\
\text { PFU) vs none }\end{array}$} & 1 & 0.4 & 0.017 & 5 vs 3 & \multirow[t]{4}{*}{$\mathrm{C} 57 \mathrm{BL} / 6$} & \multirow[t]{4}{*}{20 week } & \multirow[t]{4}{*}{ female } \\
\hline & & 2 & 2 & $<0.001$ & 5 vs 3 & & & \\
\hline & & 4 & 0.8 & 0.004 & 5 vs 3 & & & \\
\hline & & 7 & -0.3 & 0.366 & 5 vs 3 & & & \\
\hline & \multirow{4}{*}{$\begin{array}{l}\text { SARS coronavirus MA15 vs } \\
\text { none }\end{array}$} & 1 & 0.2 & 0.126 & 5 vs 3 & \multirow[t]{4}{*}{$\mathrm{C} 57 \mathrm{BL} / 6$} & \multirow[t]{4}{*}{20 week } & \multirow[t]{4}{*}{ female } \\
\hline & & 2 & 2.3 & $<0.001$ & 5 vs 3 & & & \\
\hline & & 4 & 1.1 & $<0.001$ & 5 vs 3 & & & \\
\hline & & 7 & 0.5 & 0.107 & 5 vs 3 & & & \\
\hline
\end{tabular}

Table 2. Differential Tacstd2 expression in mice after infection with various pathogens. Where not otherwise specified, viral infection dose was $10^{5}$ plaque forming units (PFU). Significant results (adjusted p-value < 0.05) are labeled in bold. * means that this entry was completely missing from Expression Atlas and $\log _{2}$-fold change was calculated from GEO database data using GEO2R. N/A means that p-value could not be calculated due to small number of subjects. 


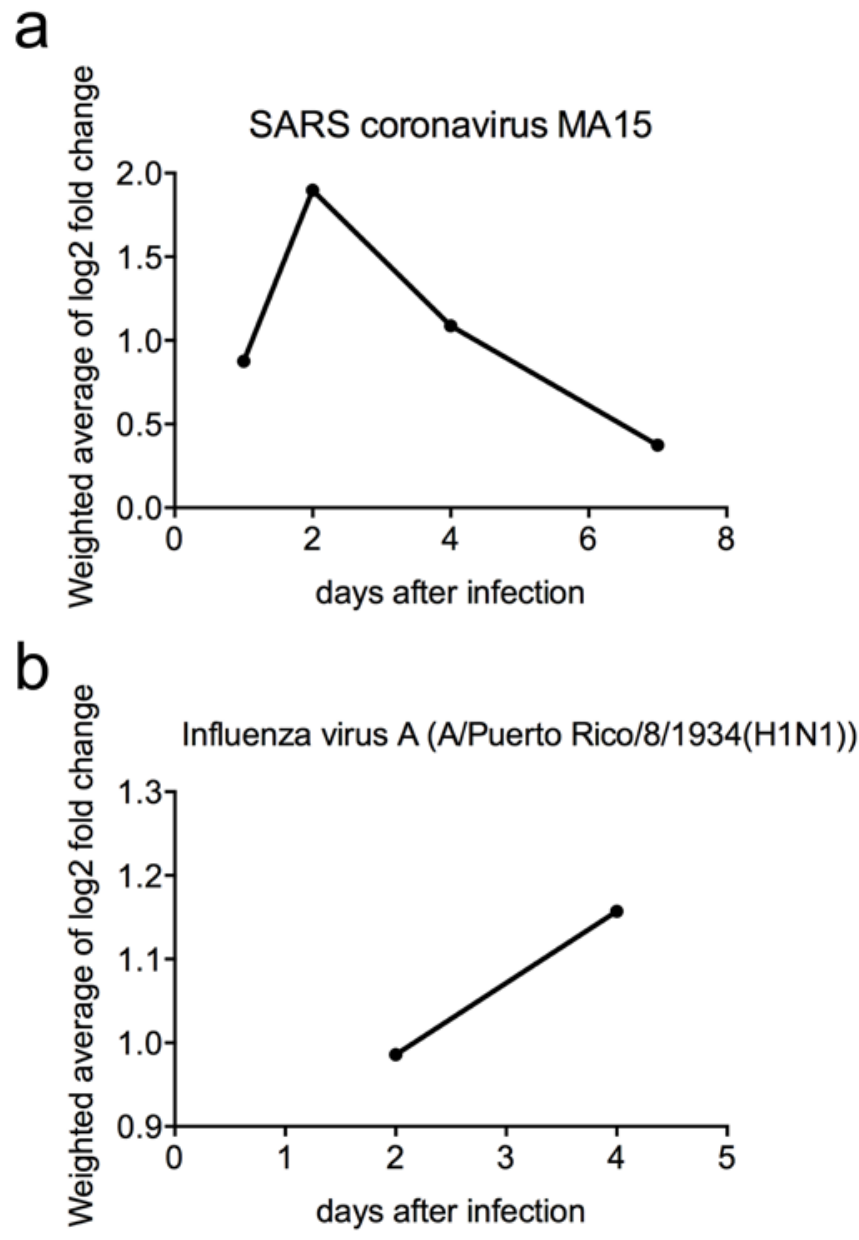

Figure 4. Weighted average of Tacstd2 $\log _{2}$-fold change after infection of mice with A) SARS coronavirus MA15 ( $n=155)$ and B) Influenza A virus $(n=42)$ at different time points. Only data from mice infected with $10^{5} \mathrm{PFU}$ in case of SARS coronavirus and $10^{2} \mathrm{PFU}$ in case of Influenza A virus are shown. Data from infection with mutant viruses were excluded.

Significant upregulation of TACSTD2 expression was also found in bronchoalveolar lavage cells in patients with transplanted lungs colonized by Aspergillus fumigatus (E-MTAB-6040). This dataset did not fulfill our inclusion criteria since it did not provide information about lung transcriptome. However, this result suggests that TACSTD2 is upregulated after fungal infection as well (Supplementary Table S1).

The single differential expression dataset (E-GEOD-19743) containing information about TACSTD2 levels after an injury did not fulfill inclusion criteria as it studied transcripts in blood and not lungs. However, it is interesting to note that it showed significantly upregulated TACSTD2 in leukocytes after burn injury in both children (60 subjects) and adults (57 subjects). More details are available in Table S2 in Supplementary data. Interestingly, levels of TACSTD2 were higher in the middle stage (1149 days) than in early stage ( $<11$ days) of the healing process after injury. 
bioRxiv preprint doi: https:/doi.org/10.1101/2021.06 29.450320: this version posted June 30,2021 . The copyright holder for this preprint (which was not certified by peer review) is the author/funder, who has granted bioRxiv a license to display the preprint in perpetuity. It is made available under aCC-BY-NC-ND 4.0 International license.

\section{TACSTD2 is upregulated in lung epithelial cells after infection}

As mentioned earlier, TACSTD2 is expressed both in lung epithelial and immune cells. It is not clear if upregulation in infected lungs is caused by increased infiltration of immune cells to the lungs or by a direct upregulation in lung epithelial cells (LECs). In order to clarify this issue, we searched GEO datasets for information about TACSTD2 expression after infection in specific cell types.

Datasets examining expression after infecting mice with influenza virus X31 (42) (GSE148709, Figure 5A), and Streptococcus pneumoniae (43) (GSE71623, Figure 5B) showed that Tacstd2 is significantly upregulated in sorted LECs when compared to uninfected cells. LECs were sorted

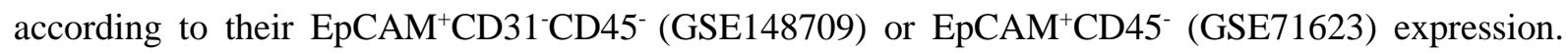
Upregulation of Tacstd2 was detected also in LECs of influenza virus X31 infected Ifnlr1 ${ }^{-/}$mice.
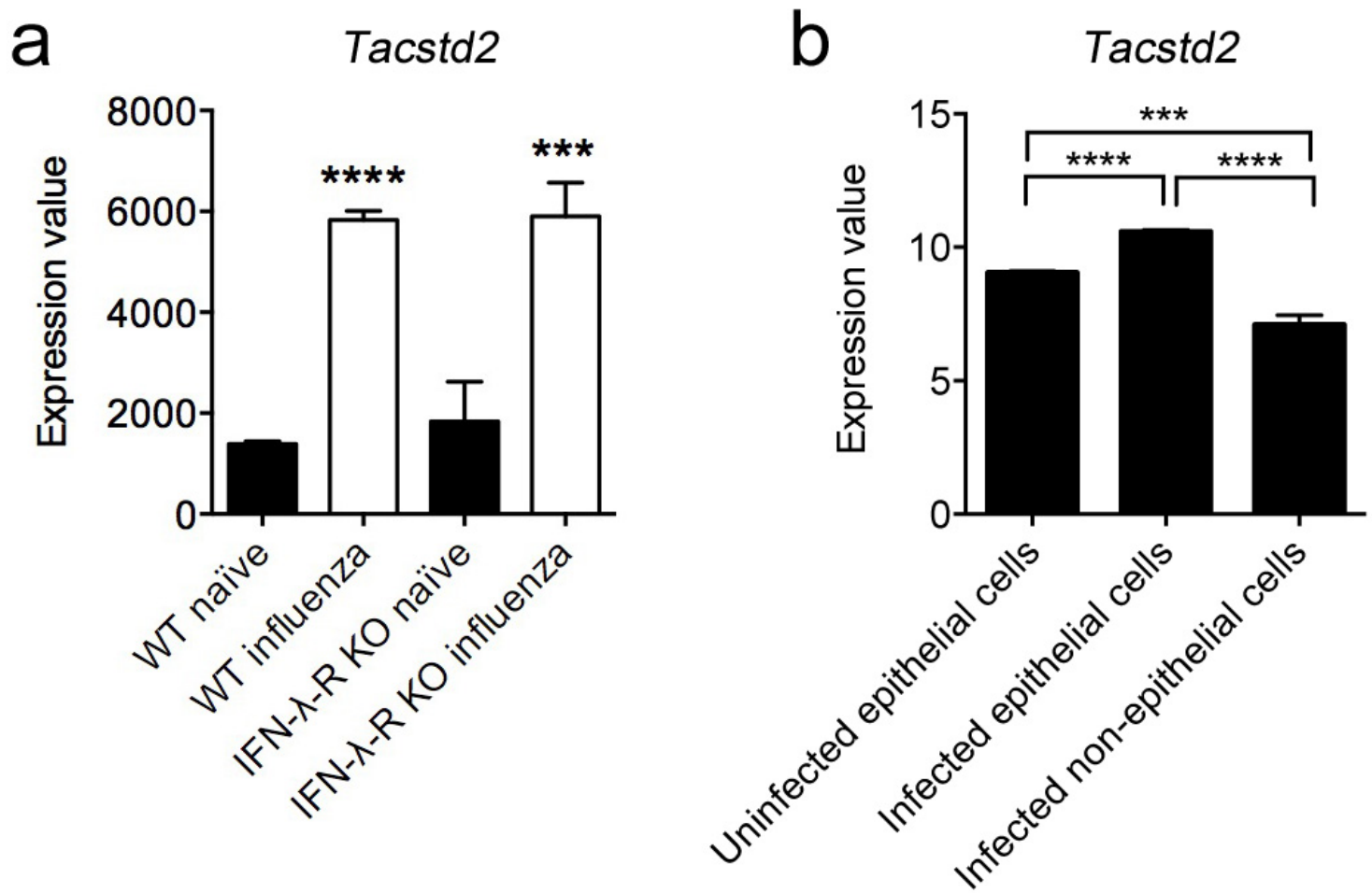

Figure 5. Tacstd2 expression in A) sorted EpCAM ${ }^{+} C D 31^{-} C D 45^{-}$LECs from wt and Ifnlr-/ mice infected or not with influenza virus X31 at 8 days after infection (GSE148709) (42), and B) sorted EpCAM ${ }^{+} C D 45^{-}$LECs from mice infected or not with Streptococcus pneumoniae at 15 hours after infection (GSE71623) (43).

Recent public dataset GSE165299 contains information about Tacstd2 expression in mouse lung resident cells. Mice were infected with influenza viruses and 3 days post-infection alveolar epithelial cells (AECs), club cells, dendritic cells (DC), mast cells, macrophages, eosinophils, and neutrophils 
were isolated and the transcriptome was analyzed by high throughput sequencing. Interestingly, after infection with influenza virus, Tacstd2 expression was increased in club cells and slightly in AECs and eosinophils, but decreased in neutrophils (Figure 6A). According to these data neutrophils of uninfected lungs have the highest basal expression of Tacstd2.



Figure 6. Heat map of TACSTD2/Tacstd2 expression A) in lung resident cells isolated from mouse lungs at 3 days post-infection (GSE165299). CD103+cDC and CD11b+cDC stay for dendritic cells. CC10 stays for club cells. AEC stays for alveolar epithelial cells. AM stays for alveolar macrophages. IM stays for intersticial macrophages. EOS stays for eosinophils, and NEU stays for neutrophils. B) in human alveolar organoids at 48 hours after infection with SARS-CoV-2 (GSE152586) (44). C) in human bronchial LECs at 36 hours after infection with various Influenza A H1N1 isolates (seasonal H1N1 BN/59, pandemic H1N1 KY/136 (non-fatal cases) and pandemic H1N1 KY/180 (fatal cases) (GDS4855) (45).

To further confirm the effect of infection on TACSTD2 upregulation in lung cells we searched for datasets examining TACSTD2 expression in LECs in vitro. TACSTD2 was upregulated in human alveolar type II cell organoids infected with SARS coronavirus 2 (44) (GSE152586, Figure 6B) as well as in well-differentiated primary human bronchial LECs infected with various influenza A isolates (45) (GDS4855, Figure 6C) when compared to uninfected cells. These data confirm that LECs contribute to the increase of TACSTD2 levels in lungs following infection.

Overall, overexpression of TACSTD2 is an early event in the lungs challenged with various infection agents. Although increased immune cell infiltration may be partially responsible for this increase, transcriptomic studies in epithelial cells sorted from lungs of infected mice and in vitro infected LECs clearly proved direct upregulation of TACSTD2. 
bioRxiv preprint doi: https//doi.org/10.1101/2021.06 29.450320; this version posted June 30, 2021. The copyright holder for this preprint

\section{Discussion}

In this article, we have analysed available transcriptomic data to decipher the function of TACSTD2 in lung tissue. Our findings may be summarized as follows. First, we have presented strong evidence that TACSTD2 is expressed in healthy lungs of various species suggesting its evolutionarily conserved role. Second and most importantly, our analyses have shown that Tacstd2 is significantly upregulated in mouse lungs following infection with various respiratory pathogens, suggesting its involvement in the healing process and/or immune reactions. Additionally, in most datasets, Tacstd2 overexpression peaks early and decreases over time, suggesting it is an early reaction to infection. In case of chronic inflammation, however, Tacstd2 remains overexpressed for long time period. The data also show that the level of Tacstd2 upregulation depend on infection dose. Third, Tacstd2 upregulation in the lungs after an infection is caused by a direct upregulation in LECs although some contribution of immune cells infiltrating infected lungs cannot be excluded.

Bacterial and viral pathogens are known violators of the airway epithelial barrier's integrity, which is the first line of defense against infection, decreasing the expression, disrupting or redistributing tight and adherens junctions proteins (46-49). Such disruption significantly contributes to the pathogenesis of pulmonary infections (48). Trop2 was previously linked with maintenance of epithelial barrier function in the cornea. TACSTD2 knockdown in corneal epithelial cells leads to decreased expression and changed subcellular localization of claudin 1, 4, 7, ZO1, and occludin which results in impaired function of corneal epithelial barrier while transduction of TACSTD2 restored their expression and epithelial barrier function (50,51). Decreased expression and altered localization of these proteins were also observed in the corneas of GDLD patients (50). Moreover, forced expression of Trop2 can at least partially stabilize claudins and restore epithelial barrier in mouse model of congenital tufting enteropathy (52). Therefore, a possible explanation of TACSTD2 upregulation following infection is that it represents a mechanism that helps maintain/restore the airway epithelial barrier function.

It has been shown that Trop2 is expressed in many organs during embryonal development, including lungs (9-15). It usually marks progenitor cells with high proliferation/self-renewal capacity. In fetal ovine and rat lungs, Trop2 expression positively correlates with proliferation rate (10). The cells exhibiting high Trop2 expression significantly contribute to tissue regeneration in stomach and endometrium $(12,22)$. In stomach, transcriptome analysis further indicated that Trop $2^{+}$cells involved in epithelial regeneration overexpress genes that are part of a fetal developmental program (12). We therefore hypothesize that the upregulation of Trop2 in (sub)population of LECs/progenitor cells may also enhance their proliferative/pro-regenerative capacity and contribute to healing process in infected lungs. It should be noted, however, that the long term Trop2 overexpression associated with inflammation may result in hyperplasia of airway epithelium as observed in lungs of COPD patients (41). 
Besides the importance of Trop2 for proper localization and function of claudins and occludins in tight junctions and possible pro-regenerative capacity of Trop2-overexpressing cells in airway epithelium, our knowledge about the role of TACSTD2/Trop2 in healthy tissues and during infection challenge remains limited. In cancer cells, high-throughput proteomic analysis revealed prosurvival PI3K/Akt as a major cellular signaling pathway stimulated by Trop2 (53). This has been confirmed subsequently in various cancer models $(54-57)$, and stem cells $(21,23)$. Activation of the Akt kinase signaling by Trop2 upregulation in response to infection may therefore enhance lung cell survival and decrease tissue damage. It should be noted, however, that controversial role of Akt kinase in modulating infection and inflammation in lungs has been reported (58,59) vs (60-63). Interestingly, both Trop2related functional targets, tight junctions proteins and Akt kinase, were reported to be hijacked by diverse viruses to promote their infection in various tissues. While tight junction proteins may participate in regulation of viral entry, replication, dissemination and progress (64-66), activation of Akt kinase may represent a strategy of viruses to slow down apoptosis of host cells, thus prolong viral replication and enhance viral transcription (63). Thorough analysis of Tacstd2 knockout mice upon infections with various pathogens is therefore needed to help clarify the exact role of the Trop2 protein and its signaling in lung tissue response to infections.

Besides Trop2, epithelial cell adhesion molecule (EpCAM, encoded by TACSTD1 gene) represents another member of TACSTD gene family (3). Both proteins share similarities in amino acid sequence, domain structure (67), processing, cell signaling and protein interaction partners $(1,68)$. Although both proteins interact with tight junction proteins $(50,69)$ and participate in maintenance of epithelial barrier $(51,70,71)$, recent study in EpCAM null mice with forced expression of Trop2 revealed that the function of both proteins is similar but not equivalent (52). Interestingly, we did not find a similar pattern of deregulation of TACSTD1 expression in lungs after infection as observed for TACSTD2 (Supplementary Table S3). This finding highlights an important distinction in regulation of expression of both genes and indicates another possible difference in their function.

Taken together, using available transcriptomic datasets we demonstrate that TACSTD2 expression is evolutionarily conserved in the lungs of vertebrates and that the major source of TACSTD2 transcript are lung epithelial cells and their progenitors. We found that lung levels of TACSTD2 consistently increase as an early reaction to infection with various respiratory pathogens. Although this increase may represent a mechanism to maintain/restore epithelial barrier function and to mark pro-regenerative activation of progenitor cells in infected lungs, further studies are needed to clarify the exact role of the Trop2 protein and its signaling during course of lung infections and healing process. 
bioRxiv preprint doi: https://doi.org/10.1101/2021.06.29.450320: this version posted June 30 2021. The copyright holder for this preprint (which was not certified by peer review) is the author/funder, who has granted bioRxiv a license to display the preprint in perpetuity. It is made available under aCC-BY-NC-ND 4.0 International license.

\section{Acnowledgement}

This work was supported by the by Ministry of Health of the Czech Republic grant NV18-07-00073, Czech Science Foundation grants no. 21-11585S, 18-001145S, Masaryk University grants MUNI/A/1689/2020, MUNI/A/1522/2020 and by the European Regional Development Fund - Project ENOCH (No. CZ.02.1.01/0.0/16_019/0000868).

\section{References}

1. Lenárt S, Lenárt P, Šmarda J, Remšík J, Souček K, Beneš P. Trop2: Jack of All Trades, Master of None. Cancers. 2020 Nov 11;12(11).

2. Remšík J, Binó L, Kahounová Z, Kharaishvili G, Šimečková Š, Fedr R, et al. Trop-2 plasticity is controlled by epithelial-to-mesenchymal transition. Carcinogenesis. 2018 Dec 13;39(11):1411-8.

3. Linnenbach AJ, Wojcierowski J, Wu SA, Pyrc JJ, Ross AH, Dietzschold B, et al. Sequence investigation of the major gastrointestinal tumor-associated antigen gene family, GA733. Proc Natl Acad Sci U S A. 1989 Jan;86(1):27-31.

4. Linnenbach AJ, Seng BA, Wu S, Robbins S, Scollon M, Pyrc JJ, et al. Retroposition in a family of carcinoma-associated antigen genes. Mol Cell Biol. 1993 Mar;13(3):1507-15.

5. El Sewedy T, Fornaro M, Alberti S. Cloning of the murine TROP2 gene: conservation of a PIP2binding sequence in the cytoplasmic domain of TROP-2. Int J Cancer. 1998 Jan 19;75(2):324-30.

6. Lipinski M, Parks DR, Rouse RV, Herzenberg LA. Human trophoblast cell-surface antigens defined by monoclonal antibodies. Proc Natl Acad Sci U S A. 1981 Aug;78(8):5147-50.

7. Stepan LP, Trueblood ES, Hale K, Babcook J, Borges L, Sutherland CL. Expression of Trop2 Cell Surface Glycoprotein in Normal and Tumor Tissues. J Histochem Cytochem. 2011 Jul;59(7):70110.

8. Trerotola M, Cantanelli P, Guerra E, Tripaldi R, Aloisi AL, Bonasera V, et al. Upregulation of Trop2 quantitatively stimulates human cancer growth. Oncogene. 2013 Jan;32(2):222-33.

9. Sozo F, Wallace MJ, Zahra VA, Filby CE, Hooper SB. Gene expression profiling during increased fetal lung expansion identifies genes likely to regulate development of the distal airways. Physiol Genomics. 2006 Jan 12;24(2):105-13.

10. McDougall ARA, Hooper SB, Zahra VA, Sozo F, Lo CY, Cole TJ, et al. The oncogene Trop2 regulates fetal lung cell proliferation. Am J Physiol Lung Cell Mol Physiol. 2011 Oct;301(4):L478-489.

11. Mustata RC, Vasile G, Fernandez-Vallone V, Strollo S, Lefort A, Libert F, et al. Identification of Lgr5-independent spheroid-generating progenitors of the mouse fetal intestinal epithelium. Cell Rep. 2013 Oct 31;5(2):421-32.

12. Fernandez Vallone V, Leprovots M, Strollo S, Vasile G, Lefort A, Libert F, et al. Trop2 marks transient gastric fetal epithelium and adult regenerating cells after epithelial damage. Dev Camb Engl. 2016 May 1;143(9):1452-63. 
bioRxiv preprint doi: https://doi.org/10.1101/2021.06.29.450320: this version posted June 30,2021 . The copyright holder for this preprint (which was not certified by peer review) is the author/funder, who has granted bioRxiv a license to display the preprint in perpetuity. It is made available under aCC-BY-NC-ND 4.0 International license.

13. Sun W, Wilhelmina Aalders T, Oosterwijk E. Identification of potential bladder progenitor cells in the trigone. Dev Biol. 2014 Sep 1;393(1):84-92.

14. Tsukahara $Y$, Tanaka M, Miyajima A. TROP2 expressed in the trunk of the ureteric duct regulates branching morphogenesis during kidney development. PloS One. 2011;6(12):e28607.

15. McDougall ARA, Wiradjaja V, Azhan A, Li A, Hale N, Wlodek ME, et al. Intrauterine Growth Restriction Alters the Postnatal Development of the Rat Cerebellum. Dev Neurosci. 2017;39(14):215-27.

16. Tsujikawa $M$, Kurahashi $H$, Tanaka $T$, Nishida $K$, Shimomura $Y$, Tano $Y$, et al. Identification of the gene responsible for gelatinous drop-like corneal dystrophy. Nat Genet. 1999 Apr;21(4):420-3.

17. Takaoka M, Nakamura T, Ban Y, Kinoshita S. Phenotypic Investigation of Cell Junction-Related Proteins in Gelatinous Drop-Like Corneal Dystrophy. Invest Ophthalmol Vis Sci. 2007 Mar 1;48(3):1095-101.

18. Aizarani N, Saviano A, Sagar null, Mailly L, Durand S, Herman JS, et al. A human liver cell atlas reveals heterogeneity and epithelial progenitors. Nature. 2019 Aug;572(7768):199-204.

19. Goldstein AS, Lawson DA, Cheng D, Sun W, Garraway IP, Witte ON. Trop2 identifies a subpopulation of murine and human prostate basal cells with stem cell characteristics. Proc Natl Acad Sci U S A. 2008 Dec 30;105(52):20882-7.

20. Okabe M, Tsukahara Y, Tanaka M, Suzuki K, Saito S, Kamiya Y, et al. Potential hepatic stem cells reside in EpCAM+ cells of normal and injured mouse liver. Development. 2009 Jun 1;136(11):1951-60.

21. Yang J, Zhu Z, Wang H, Li F, Du X, Ma RZ. Trop2 regulates the proliferation and differentiation of murine compact-bone derived MSCs. Int J Oncol. 2013 Sep;43(3):859-67.

22. Memarzadeh S, Zong $\mathrm{Y}$, Janzen DM, Goldstein AS, Cheng D, Kurita T, et al. Cell-autonomous activation of the PI3-kinase pathway initiates endometrial cancer from adult uterine epithelium. Proc Natl Acad Sci U S A. 2010 Oct 5;107(40):17298-303.

23. Li T, Su Y, Yu X, Mouniir DSA, Masau JF, Wei X, et al. Trop2 Guarantees Cardioprotective Effects of Cortical Bone-Derived Stem Cells on Myocardial Ischemia/Reperfusion Injury. Cell Transplant. 2018 Aug;27(8):1256-68.

24. Wang J, Zhang K, Grabowska D, Li A, Dong Y, Day R, et al. Loss of Trop2 promotes carcinogenesis and features of epithelial to mesenchymal transition in squamous cell carcinoma. Mol Cancer Res MCR. 2011 Dec;9(12):1686-95.

25. Dreyfuss D, Ricard J-D. Acute lung injury and bacterial infection. Clin Chest Med. 2005 Mar;26(1):105-12.

26. GBD 2017 Causes of Death Collaborators. Global, regional, and national age-sex-specific mortality for 282 causes of death in 195 countries and territories, 1980-2017: a systematic analysis for the Global Burden of Disease Study 2017. Lancet Lond Engl. 2018 Nov 10;392(10159):1736-88. 
bioRxiv preprint doi: https:/doi.org/10.1101/2021.06 29.450320: this version posted June 30,2021 . The copyright holder for this preprint (which was not certified by peer review) is the author/funder, who has granted bioRxiv a license to display the preprint in perpetuity. It is made available under aCC-BY-NC-ND 4.0 International license.

27. Osuka A, Ogura $H$, Ueyama $M$, Shimazu $T$, Lederer JA. Immune response to traumatic injury: harmony and discordance of immune system homeostasis. Acute Med Surg. 2014 Jan 28;1(2):639.

28. Stoecklein VM, Osuka A, Lederer JA. Trauma equals danger--damage control by the immune system. J Leukoc Biol. 2012 Sep;92(3):539-51.

29. Huber-Lang M, Lambris JD, Ward PA. Innate immune responses to trauma. Nat Immunol. 2018 Apr;19(4):327-41.

30. Papatheodorou I, Moreno P, Manning J, Fuentes AM-P, George N, Fexova S, et al. Expression Atlas update: from tissues to single cells. Nucleic Acids Res. 2020 Jan 8;48(D1):D77-83.

31. Uhlén M, Fagerberg L, Hallström BM, Lindskog C, Oksvold P, Mardinoglu A, et al. Proteomics. Tissue-based map of the human proteome. Science. 2015 Jan 23;347(6220):1260419.

32. Lonsdale J, Thomas J, Salvatore M, Phillips R, Lo E, Shad S, et al. The Genotype-Tissue Expression (GTEx) project. Nat Genet. 2013 Jun;45(6):580-5.

33. Bastian FB, Roux J, Niknejad A, Comte A, Fonseca Costa SS, de Farias TM, et al. The Bgee suite: integrated curated expression atlas and comparative transcriptomics in animals. Nucleic Acids Res. 2021 Jan 8;49(D1):D831-47.

34. Benjamini Y, Hochberg Y. Controlling the False Discovery Rate: A Practical and Powerful Approach to Multiple Testing. J R Stat Soc Ser B Methodol. 1995;57(1):289-300.

35. Barrett T, Wilhite SE, Ledoux P, Evangelista C, Kim IF, Tomashevsky M, et al. NCBI GEO: archive for functional genomics data sets--update. Nucleic Acids Res. 2013 Jan;41(Database issue):D991995.

36. Travaglini KJ, Nabhan AN, Penland L, Sinha R, Gillich A, Sit RV, et al. A molecular cell atlas of the human lung from single-cell RNA sequencing. Nature. 2020 Nov;587(7835):619-25.

37. Vieira Braga FA, Kar G, Berg M, Carpaij OA, Polanski K, Simon LM, et al. A cellular census of human lungs identifies novel cell states in health and in asthma. Nat Med. 2019 Jul;25(7):1153-63.

38. Yu Y, Fuscoe JC, Zhao C, Guo C, Jia M, Qing T, et al. A rat RNA-Seq transcriptomic BodyMap across 11 organs and 4 developmental stages. Nat Commun. 2014 Feb 10;5(1):3230.

39. Angelidis I, Simon LM, Fernandez IE, Strunz M, Mayr CH, Greiffo FR, et al. An atlas of the aging lung mapped by single cell transcriptomics and deep tissue proteomics. Nat Commun. 2019 Feb 27;10(1):963.

40. Kim EY, Battaile JT, Patel AC, You Y, Agapov E, Grayson MH, et al. Persistent activation of an innate immune axis translates respiratory viral infection into chronic lung disease. Nat Med. 2008 Jun;14(6):633-40.

41. Liu Q, Li H, Wang Q, Zhang Y, Wang W, Dou S, et al. Increased expression of TROP2 in airway basal cells potentially contributes to airway remodeling in chronic obstructive pulmonary disease. Respir Res. 2016 Nov 25;17(1):159. 
bioRxiv preprint doi: https://doi.org/10.1101/2021.06.29.450320: this version posted June 30,2021 . The copyright holder for this preprint (which was not certified by peer review) is the author/funder, who has granted bioRxiv a license to display the preprint in perpetuity. It is made available under aCC-BY-NC-ND 4.0 International license.

42. Major J, Crotta S, Llorian M, McCabe TM, Gad HH, Priestnall SL, et al. Type I and III interferons disrupt lung epithelial repair during recovery from viral infection. Science. 2020 Aug 7;369(6504):712-7.

43. Kamata H, Yamamoto K, Wasserman GA, Zabinski MC, Yuen CK, Lung WY, et al. Epithelial CellDerived Secreted and Transmembrane 1a Signals to Activated Neutrophils during Pneumococcal Pneumonia. Am J Respir Cell Mol Biol. 2016 Sep;55(3):407-18.

44. Katsura H, Sontake V, Tata A, Kobayashi Y, Edwards CE, Heaton BE, et al. Human Lung Stem CellBased Alveolospheres Provide Insights into SARS-CoV-2-Mediated Interferon Responses and Pneumocyte Dysfunction. Cell Stem Cell. 2020 Dec 3;27(6):890-904.e8.

45. Gerlach RL, Camp JV, Chu Y-K, Jonsson CB. Early host responses of seasonal and pandemic influenza $A$ viruses in primary well-differentiated human lung epithelial cells. PloS One. 2013;8(11):e78912.

46. Rezaee F, Georas SN. Breaking Barriers. New Insights into Airway Epithelial Barrier Function in Health and Disease. Am J Respir Cell Mol Biol. 2014 Jan 27;50(5):857-69.

47. Soong G, Parker D, Magargee M, Prince AS. The Type III Toxins of Pseudomonas aeruginosa Disrupt Epithelial Barrier Function. J Bacteriol. 2008 Apr 15;190(8):2814-21.

48. Short KR, Kasper J, Aa S van der, Andeweg AC, Zaaraoui-Boutahar F, Goeijenbier M, et al. Influenza virus damages the alveolar barrier by disrupting epithelial cell tight junctions. Eur Respir J. 2016 Mar 1;47(3):954-66.

49. Linfield DT, Raduka A, Aghapour M, Rezaee F. Airway tight junctions as targets of viral infections. Tissue Barriers. 2021 Apr 3;9(2):1883965.

50. Nakatsukasa M, Kawasaki S, Yamasaki K, Fukuoka H, Matsuda A, Tsujikawa M, et al. TumorAssociated Calcium Signal Transducer 2 Is Required for the Proper Subcellular Localization of Claudin 1 and 7: Implications in the Pathogenesis of Gelatinous Drop-Like Corneal Dystrophy. Am J Pathol. 2010 Sep 1;177(3):1344-55.

51. Xu P, Kai C, Kawasaki S, Kobayashi Y, Yamamoto K, Tsujikawa M, et al. A New in Vitro Model of GDLD by Knocking Out TACSTD2 and Its Paralogous Gene EpCAM in Human Corneal Epithelial Cells. TransI Vis Sci Technol. 2018 Nov;7(6):30.

52. Nakato G, Morimura S, Lu M, Feng X, Wu C, Udey MC. Amelioration of Congenital Tufting Enteropathy in EpCAM (TROP1)-Deficient Mice via Heterotopic Expression of TROP2 in Intestinal Epithelial Cells. Cells [Internet]. 2020 Aug 6;9(8). Available from: https://www.ncbi.nlm.nih.gov/pmc/articles/PMC7465201/

53. Guerra E, Trerotola M, Tripaldi R, Aloisi AL, Simeone P, Sacchetti A, et al. Trop-2 Induces Tumor Growth Through AKT and Determines Sensitivity to AKT Inhibitors. Clin Cancer Res. 2016 Aug 15;22(16):4197-205.

54. Tang $G$, Tang $Q$, Jia $L$, Chen $Y$, Lin $L$, Kuai $X$, et al. TROP2 increases growth and metastasis of human oral squamous cell carcinoma through activation of the PI3K/Akt signaling pathway. Int J Mol Med. 2019 Dec;44(6):2161-70. 
bioRxiv preprint doi: https://doi.org/10.1101/2021.06.29.450320: this version posted June 30,2021 . The copyright holder for this preprint (which was not certified by peer review) is the author/funder, who has granted bioRxiv a license to display the preprint in perpetuity. It is made available under aCC-BY-NC-ND 4.0 International license.

55. Li X, Teng S, Zhang Y, Zhang W, Zhang $X$, Xu K, et al. TROP2 promotes proliferation, migration and metastasis of gallbladder cancer cells by regulating PI3K/AKT pathway and inducing EMT. Oncotarget. 2017 Apr 3;8(29):47052-63.

56. Gu Q-Z, Nijiati A, Gao X, Tao K-L, Li C-D, Fan X-P, et al. TROP2 promotes cell proliferation and migration in osteosarcoma through PI3K/AKT signaling. Mol Med Rep. 2018 Aug 1;18(2):1782-8.

57. Sun X, Xing G, Zhang C, Lu K, Wang Y, He X. Knockdown of Trop2 inhibits proliferation and migration and induces apoptosis of endometrial cancer cells via AKT/ $\beta$-catenin pathway. Cell Biochem Funct. 2020 Mar;38(2):141-8.

58. Gopallawa I, Lee RJ. Targeting the phosphoinositide-3-kinase/protein kinase B pathway in airway innate immunity. World J Biol Chem. 2020 Sep 27;11(2):30-51.

59. Qiao S, Zheng N, Sun L, Pang G, Wang S, Jia P, et al. The p1108 isoforme of phosphatidylinositol 3-kinase plays an important role in host defense against chlamydial lung infection through influencing CD4+ T-cell function. Pathog Dis. 2018 Aug 1;76(6).

60. García-Fojeda B, González-Carnicero Z, de Lorenzo A, Minutti CM, de Tapia L, Euba B, et al. Lung Surfactant Lipids Provide Immune Protection Against Haemophilus influenzae Respiratory Infection. Front Immunol [Internet]. 2019 [cited 2021 Apr 28];10. Available from: https://www.frontiersin.org/articles/10.3389/fimmu.2019.00458/full

61. Guo Q, Shen N, Yuan K, Li J, Wu H, Zeng Y, et al. Caveolin-1 plays a critical role in host immunity against Klebsiella pneumoniae by regulating STAT5 and Akt activity. Eur J Immunol. 2012 Jun;42(6):1500-11.

62. Yang Z, Zou X, Feng P, Zhan H, Xiong D, Lang J. Inhibition of the PI3K/AKT Signaling Pathway or Overexpression of Beclin1 Blocks Reinfection of Streptococcus pneumoniae After Infection of Influenza A Virus in Severe Community-Acquired Pneumonia. Inflammation. 2019 Oct;42(5):1741-53.

63. Dai X, Zhang L, Hong T. Host cellular signaling induced by influenza virus. Sci China Life Sci. 2011 Jan;54(1):68-74.

64. Torres-Flores JM, Arias CF. Tight Junctions Go Viral! Viruses. 2015 Sep 23;7(9):5145-54.

65. Colpitts CC, Baumert TF. Claudins in viral infection: From entry to spread. Pflugers Arch. 2017 Jan;469(1):27-34.

66. Sekhar V, Pollicino T, Diaz G, Engle RE, Alayli F, Melis M, et al. Infection with hepatitis C virus depends on TACSTD2, a regulator of claudin-1 and occludin highly downregulated in hepatocellular carcinoma. PLoS Pathog. 2018 Mar;14(3):e1006916.

67. Szala S, Froehlich M, Scollon M, Kasai Y, Steplewski Z, Koprowski H, et al. Molecular cloning of cDNA for the carcinoma-associated antigen GA733-2. Proc Natl Acad Sci. 1990 May 1;87(9):35426.

68. Mashhadi SMY, Kazemimanesh M, Arashkia A, Azadmanesh K, Meshkat Z, Golichenari B, et al. Shedding light on the EpCAM: An overview. J Cell Physiol. 2019;234(8):12569-80.

69. Wu C-J, Mannan P, Lu M, Udey MC. Epithelial cell adhesion molecule (EpCAM) regulates claudin dynamics and tight junctions. J Biol Chem. 2013 Apr 26;288(17):12253-68. 
bioRxiv preprint doi: https://doi.org/10.1101/2021.06.29.450320; this version posted June 30, 2021. The copyright holder for this preprint (which was not certified by peer review) is the author/funder, who has granted bioRxiv a license to display the preprint in perpetuity. It is made available under aCC-BY-NC-ND 4.0 International license.

70. Kozan PA, McGeough MD, Peña CA, Mueller JL, Barrett KE, Marchelletta RR, et al. Mutation of EpCAM leads to intestinal barrier and ion transport dysfunction. J Mol Med Berl Ger. 2015;93(5):535-45.

71. Wu C-J, Lu M, Feng X, Nakato G, Udey MC. Matriptase Cleaves EpCAM and TROP2 in Keratinocytes, Destabilizing Both Proteins and Associated Claudins. Cells. 2020 Apr;9(4):1027. 